\title{
Ractopamine hydrochloride and immunological castration in pigs. Part 1: fresh belly characteristics for bacon processing and quality
}

\author{
Letícia Cristina COSTA E SILVA ${ }^{1 \star}$, Roger Darros BARBOSA ${ }^{1}$, Dustin Dee BOLER ${ }^{2}$, \\ Expedito Tadeu Facco SILVEIRA ${ }^{3 \dagger}$
}

\begin{abstract}
The effects of ractopamine and immunological castration on belly characteristics, processing yield, physicochemical and sensory quality of bacon were investigated from two crossbred pigs under different conditions of animal production, diet, management and slaughter arranged in factorial design using 2 ractopamine levels ( 0 and $7.5 \mathrm{ppm})$ and 3 genders (barrows, immunocastrated and gilts). Before processing, belly firmness, weight, length, width and thickness were measured, and then, bacon processing yield evaluated. After processing, bacon slices were digitally imaged and analyzed for lean meat and fat areas, $\mathrm{pH}$, instrumental color of meat and fat, cooking loss and sensory quality. The ractopamine did not alter belly characteristics, but significantly increased the process yield and decreased cooking loss. Barrows and immunocastrated pigs showed firmer bellies, which could be advantageous for bacon processing and slicing. Barrows presented the highest total area of bacon slices. The results of this study indicate that both techniques ractopamine in the finishing diets and immunocastration of pigs can be combined with no further consequences for belly processing and to bacon quality and with some advantages.
\end{abstract}

Keywords: bacon; belly characteristics; digital imaging; sensory; immunological castration; ractopamine hydrochloride.

Practical Application: Belly and bacon processing pork industry linked to male immunocastration and Ractopamine fed pigs.

\section{Introduction}

Physical castration is a common practice used in several parts of the world to reduce the occurrence of boar taint in male pigs. Boar taint is mainly caused by high concentrations of androstenone, skatole and/or indole in the adipose tissue (Vold, 1970 cited by Font i Furnols et al., 2008). Physical castration also reduces growth performance and increases fat deposition (Dunshea et al., 2001; Rikard-Bell et al., 2009). Immunological castration is a technique used to induce the pig's body to produce antibodies against gonadotropin releasing factor (GnRF). This causes a cascade of events that stops testosterone production and ultimately leads to the elimination of boar taint compounds (Fayrer-Hosken, 2008) and is just as effective as physical castration at protecting against boar taint (Dunshea et al., 2001). Immunocastration also helps to increase animal feed intake after the second vaccine application (Oliver et al., 2003).

Ractopamine hydrochloride is a repartitioning agent added to finishing diets to improve swine growth performance. It acts as a modifier of animal metabolism, changing the partition of nutrient by diverting and promoting growth and deposition of lean tissue and reducing fat in the carcass of finishing pigs (Apple et al., 2004) and aiming to improve carcass quality (Gonzalez et al., 2010).
The effects of immunocastration and ractopamine feeding on pork have been studied showing positive results of these technologies on feed conversion efficiency and quantity of lean meat, which may result in economic benefits (Brumatti \& Kiefer, 2010). Additionally, ractopamine has been reported to have beneficial or non-detrimental impact on processing characteristics in hams (Boler et al., 2010), belly (Tavárez et al., 2012); loin and belly (Scramlin et al., 2008).

Bacon consumption has experienced extensive growth over the last 25 years. This trend has had an important effect on the pork industry by increasing demand for and value of fresh pork bellies (Person et al., 2005).

Although much is known about the effects of ractopamine on growth and carcass characteristics and new information continues to become available for immunological castration, little is known about the interactive effects between the two technologies (Rikard-Bell et al., 2009). Still, little is known about fresh belly and processing characteristics of immunological castration fed ractopamine pigs. Therefore, the objective of this study was to determine the effects of ractopamine hydrochloride on fresh belly characteristics and processing for bacon quality of immunologically and physically castrated males and gilts 
originated from two different crossbred pigs under different conditions of animal production, diet, management and slaughter.

\section{Materials and methods}

\subsection{Animals and treatments}

All procedures involving live animals in this study were approved by the Committee of Ethics in Animal Experimentation in Campinas, Brazil, according to Brazilian federal standards (Brasil, 2000).

The experimental study started with 310 pigs (95 gilts, 107 immunocastrates and 108 physically castrated barrows), weighing 108-129 kg. Pigs were from two genetic lines, "Topigs, Large White x Landrace x Duroc" (202) available in Agua Branca farm, located in Fartura, and "Agroceres PIC, Duroc x Landrace x Pietran" (108) available in Bressiani farm, located in Capivari, both in the state of São Paulo.

The factorial arrangement applied was as follows: 2 dietary ractopamine levels 0 and $7.5 \mathrm{ppm}$ (Ractosuin ${ }^{\circ}$, Ourofino Agribusiness) and 3 genders (physically castrated males, immunologically castrated males and gilts) of animals blocked into two different farms (Agua Branca and Bressiani) of two different genetic crossbred pigs under different conditions of production (management, nutrient intake, environment) and slaughter. Pigs were housed on solid-concrete floor pens and provided with ad libitum access to feed and water. Part of the male animals (entire), randomly selected, was physically castrated (performed in piglets aged 3 to 5 days) and the other part was immunocastrated (Vivax ${ }^{\oplus}$, Pfizer Animal Health, doses at 8 and 4 weeks before slaughter). Within each sex group, animals were allocated to get different levels of dietary ractopamine. Ractopamine was administered during 21 days before slaughter in conventional diet based on corn and soybean formulated with $16 \%$ protein and $0.91 \%$ lysine.

\subsection{Slaughter and carcass cut-out analysis}

The animals were slaughtered according to the Regulation of the Industrial and Sanitary Inspection of Animal Products (Brasil, 1997). After slaughter, using the Hennessy Grading Probe' (Hennessy Grading Systems GP4/BP4, DIDAI), hot half carcasses were evaluated by weight ranging from 46 to $51 \mathrm{~kg}$, fat thickness from 15 to $20 \mathrm{~mm}$ and muscle thickness from 64 to $68 \mathrm{~mm}$, respectively from the two commercial farms.
Sixty bellies were selected (five from each treatment), weighed whole, without spareribs, and trimmed, according to Brazilian standards specifications (Brasil, 1997).

\subsection{Fresh belly physical characteristics measurements}

Belly length and width were measured into 3 rows (back, middle and front end) from caudal to cranial. Belly firmness was determined by placing the geometric center of each belly on a stationary rod and measuring the distance from each skin edge, according to Rentfrow et al. (2003). Thickness was measured using a sharp micrometer instrument with the skin side down at eight different locations (Figure 1a).

\subsection{Bacon processing yield evaluation}

Bellies were transported to an industrial plant and weighed before (green weight) and after dry curing with $\mathrm{NaCl}, \mathrm{NaNO}_{2}$ and garlic for $72 \mathrm{~h}$ to evaluate process uptake, expressed as dry curing yield \%, according to Equation 1. Bellies were hung in a smokehouse rack, and cooked to an internal temperature of $71 \pm 1^{\circ} \mathrm{C}$ according to the plant commercial protocol. Bacon was water washed for $10 \mathrm{~min}$, drip dried for $15 \mathrm{~min}$, and then chilled overnight at $2 \pm 1{ }^{\circ} \mathrm{C}$. Next morning, each bacon was weighed to determine process yield (4 replications), using Equation 2.

Dry Curing Yield $(\%)=\frac{\text { after curing weight }(\mathrm{g})}{\text { green weight }(\mathrm{g})}$

Process Yield $(\%)=\frac{\text { after processing weight }(\mathrm{g})}{\text { green weight }(\mathrm{g})} 100$

\subsection{Bacon lean meat and fat evaluation}

Each bacon was then cut at back, middle and front end. Slices $(1.30 \mathrm{~cm}$ thickness) were digitally imaged and pictures were analyzed using Adobe Photoshop CS4 extended (Scramlin et al., 2008). The images were analyzed for primary and secondary lean meat area and the total area. The results were expressed as total area $\left(\mathrm{cm}^{2}\right)$ of bacon slice, primary and secondary lean meat areas $\left(\mathrm{cm}^{2}\right)$, percentage of meat area and percentage of fat area (Figure 1b).

\subsection{Bacon pH and color measurements}

Objective CIELab color scores were collected using Minolta Chroma Meter (model CR-400, Konica Minolta Sensing. Inc., New Jersey, USA) with illuminant D65 and a $10^{\circ}$ observer angle (a)

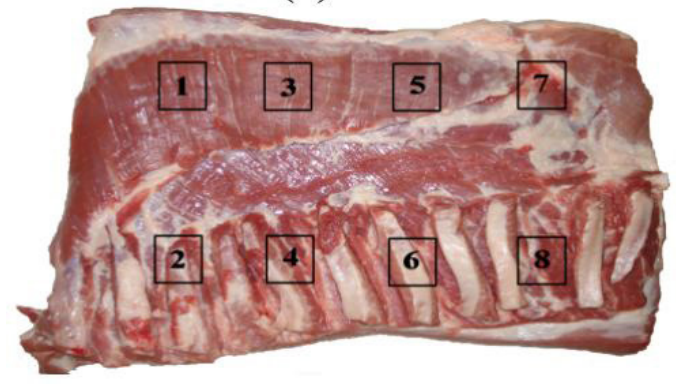

(b)

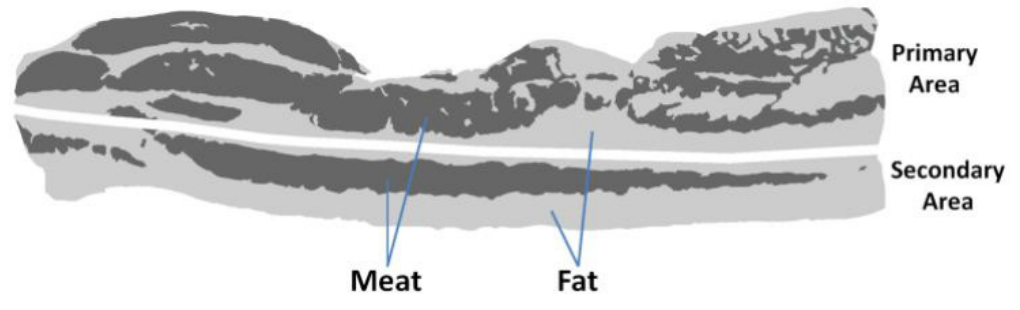

Figure 1. Belly thickness measurements taken at eight points (a) and bacon outlined image for meat and fat areas (b). Source: Leticia C. C. Silva. 
calibrated with standard white ceramic tile. The color parameters lightness $L^{*}(0=$ black; $100=$ white $)$, and what positive and negative $\mathrm{a}^{*}$ and $\mathrm{b}^{*}$ coordinates represent $\left(\mathrm{a}^{*}:+=\right.$ red, $-=$ green; $b^{\star}:+=$ yellow, $-=$ blue) were recorded. The color scores were obtained and averaged from four measurements (fat and lean) taken on the same surface points of bacon slices for each treatment. The $\mathrm{pH}$ was determined using $\mathrm{pH}$-meter Hanna Instruments (model HI99163, Woonsocket, USA), calibrated at pH 4.0 and 7.0; the results were averaged among four measurements of bacon slices for each treatment.

\subsection{Cooking loss of bacon measurement}

Three slices of bacon were cut, weighed and cooked on an electric grill (model GBZ31SB, George Foreman Grill). Bacon slices were placed on the preheated grill at $180 \pm 1{ }^{\circ} \mathrm{C}$ for $10 \mathrm{~min}$. Immediately after removal from the grill, the slices were placed on paper towel for 10 minutes to remove excess fat and weighed again. The cooking loss was calculated using Equation 3.

$$
\text { Cooking loss }(\%)=\frac{\text { raw weight }(\mathrm{g})-\text { cooked weight }(\mathrm{g})}{\text { raw weight }(\mathrm{g})} 100
$$

\subsection{Sensory analysis of bacon}

One hundred sixty four consumers, in a supermarket (city of Campinas, Brazil), were randomly selected and no pre-selection for any ability for perception of odor or appearance of bacon. Samples, labeled with three-digit random numbers, were served to the consumers in a monadic way and in different orders following an incomplete block design. Consumers were asked to evaluate the product appearance and odor. The judgments were expressed individually by scoring each sample for odor and appearance on a modified 9-point hedonic scale. Consumers were also requested to respond about their purchase intention.

Prior to the sensory analysis of bacon flavor, microbiological analyzes were carried out according to RDC 12 (Agência Nacional de Vigilância Sanitária, 2001). The lactic acid bacteria results showed high microbial counts, therefore, flavor analysis was not performed.

\subsection{Statistical analysis}

For belly characteristics and bacon quality, a randomized factorial $2 \times 3$ block design was used. The statistical model included the main effects of adding two dietary ractopamine levels ( 0 vs $7.5 \mathrm{ppm})$ and the three genders (barrows vs immunocastrated vs gilts) besides interaction between main effects (ractopamine and gender), in blocks of two different genetics and conditions of production (management, nutrient intake, environment) and slaughter from the farms Agua Branca and Bressiani. In case of significant interactions $(P<0.05)$ in ANOVA analysis, the Tukey test was proceeded for multiple comparison of means. Statistical data analysis was carried out using Statistica 7 (StatSoft, 2004).

\section{Results and discussion}

Tables 1 and 2 present the results for belly characteristics, processing yields and the physicochemical quality of bacon. There was a significant effect $(P<0.05)$ due to gender for dry curing yield, firmness, thickness and weight, and due to ractopamine for dry curing and process yields. Results show significant effect $(P<0.05)$ only for gender on $\mathrm{pH}$ and for ractopamine fed pigs on cooking loss.

Ractopamine level as affected on process and dry curing yields as well as on belly physical characteristics are depicted in Table 1. The addition of ractopamine did not alter $(P>0.05)$ length, width, firmness, thickness and belly weight, however, ractopamine increased significantly $(P<0.05)$ dry curing yield and the process yield to about $1.5 \%$ compared to pigs with no dietary ractopamine, with benefits to the bacon industry. Similar results were reported by Scramlin et al. (2008), who studied pigs fed with different dietary ractopamine levels, where no differences were observed in average belly thickness, length, weight and firmness between the control and ractopamine $(7.4 \mathrm{ppm})$ group. In the same study, belly yield during processing showed no differences $(P>0.05)$, which might be due to a different processing method used, where curing was carried out with the injection of brine at approximately $110 \%$ of the original green weight. Similarly, other results reported by Leick et al. (2010) and Stites et al. (1991), showed no impact of ractopamine (at 5 or $10 \mathrm{ppm}$ ) on belly length, width and thickness, as well as no impact on firmness.

Table 1. Results of belly characteristics and processing yields as a function of gender and ractopamine level.

\begin{tabular}{|c|c|c|c|c|c|c|c|c|}
\hline & & $\begin{array}{c}\text { Firmness } \\
(\mathrm{cm})\end{array}$ & $\begin{array}{l}\text { Length } \\
(\mathrm{cm})\end{array}$ & $\begin{array}{c}\text { Width } \\
(\mathrm{cm})\end{array}$ & $\begin{array}{l}\text { Thickness } \\
(\mathrm{cm})\end{array}$ & $\begin{array}{l}\text { Belly weight } \\
(\mathrm{kg})\end{array}$ & $\begin{array}{l}\text { Dry curing } \\
\text { yield }(\%)\end{array}$ & $\begin{array}{c}\text { Process yield } \\
(\%)\end{array}$ \\
\hline \multirow{4}{*}{ Gender } & Gilt & $11.59^{\mathrm{b}}$ & 36.40 & 25.17 & $3.454^{\mathrm{ab}}$ & $3.647^{\mathrm{b}}$ & $100.2^{\mathrm{b}}$ & 82.63 \\
\hline & Barrow & $14.61^{\mathrm{a}}$ & 37.76 & 25.92 & $3.668^{\mathrm{a}}$ & $4.332^{\mathrm{a}}$ & $101.7^{\mathrm{a}}$ & 83.97 \\
\hline & SEM & 0.798 & 0.675 & 0.506 & 0.075 & 0.145 & 0.175 & 0.479 \\
\hline & $P$-value & 0.020 & 0.251 & 0.306 & 0.045 & 0.001 & 0.030 & 0.106 \\
\hline \multirow{3}{*}{$\begin{array}{l}\text { Ractopamine } \\
\quad(\mathrm{ppm})\end{array}$} & SEM & 0.687 & 0.543 & 0.413 & 0.064 & 0.129 & 0.141 & 0.430 \\
\hline & $P$-value & 0.318 & 0.067 & 0.414 & 0.099 & 0.345 & 0.002 & 0.041 \\
\hline & $\mathrm{CV}(\%)$ & 26.6 & 7.29 & 7.91 & 9.52 & 17.8 & 0.72 & 2.62 \\
\hline
\end{tabular}

${ }^{\mathrm{ab}}$ Means within the same column with different superscripts differ significantly at $5 \%$ level of significance for gender and ractopamine level. SEM: Standard error of the mean for all treatments; CV: Coefficient of variation. 
Table 2. Results of physicochemical quality of bacon as a function of gender and ractopamine level.

\begin{tabular}{|c|c|c|c|c|c|c|c|c|c|}
\hline & & \multicolumn{3}{|c|}{ Meat Color } & \multicolumn{3}{|c|}{ Fat Color } & \multirow{2}{*}{$\mathrm{pH}$} & \multirow{2}{*}{$\begin{array}{l}\text { Cooking } \\
\text { Loss (\%) }\end{array}$} \\
\hline & & $L^{*}$ & $\mathrm{a}^{*}$ & $\mathrm{~b}^{*}$ & $L^{*}$ & $\mathrm{a}^{*}$ & $b^{*}$ & & \\
\hline \multirow{4}{*}{ Gender } & Gilt & 47.55 & 11.02 & 4.889 & 61.51 & 4.803 & 3.921 & $5.970^{\mathrm{a}}$ & 47.30 \\
\hline & Barrow & 45.66 & 11.87 & 5.061 & 62.92 & 5.040 & 3.938 & $5.916^{\mathrm{ab}}$ & 50.09 \\
\hline & SEM & 1.147 & 0.358 & 0.172 & 0.745 & 0.374 & 0.196 & 0.034 & 1.271 \\
\hline & $P$-value & 0.491 & 0.260 & 0.927 & 0.124 & 0.101 & 0.483 & 0.048 & 0.332 \\
\hline \multirow{3}{*}{$\begin{array}{l}\text { Ractopamine } \\
(\text { ppm })\end{array}$} & SEM & 0.939 & 0.292 & 0.141 & 0.617 & 0.301 & 0.158 & 0.029 & 0.996 \\
\hline & $P$-value & 0.953 & 0.667 & 0.293 & 0.373 & 0.327 & 0.619 & 0.887 & 0.022 \\
\hline & CV (\%) & 11.2 & 14.5 & 27.7 & 11.6 & 34.1 & 18.3 & 2.13 & 9.70 \\
\hline
\end{tabular}

${ }^{\mathrm{ab}}$ Means within the same column with different superscripts differ significantly at 5\% level of significance for gender and ractopamine level, SEM: Standard error of the mean for all treatments; CV: Coefficient of variation. $\mathrm{L}^{*}$ : Lightness; $\mathrm{a}^{*}$ : Redness; $\mathrm{b}^{*}$ : Yellowness.

The results showed no interactions $(P>0.05)$ between gender and ractopamine on belly characteristics and processing yields. Uttaro et al. (1993) reported no interaction effect (gender and ractopamine) on process yield $(P>0.05)$ in barrows and gilts fed with $20 \mathrm{ppm}$ of ractopamine compared to pigs not fed with repartitioning agents. Scramlin et al. (2008), in a study of ractopamine on diets observed a trend in reducing the positive effects of ractopamine on bacon and belly quality as the level increases from 5 to $7.4 \mathrm{ppm}$. This may result from either saturation of the $\beta$-agonist receptors or a decrease in receptor density due to down regulations, thereby reducing the impact of the ractopamine on diet.

Pigs that received dietary ractopamine showed higher dry curing and process yields (Table 1). There is also a major concern in the use of repartitioning agents since the belly may possibly become thinner and consequently reducing process yield (Crome et al., 1996). The current data obtained showed a positive effect on process yield without requiring an increase in belly thickness which would be beneficial to the bacon industry.

The influence of gender on belly characteristics was clearly observed by the significant effect (at 5\% level of significance) on firmness, thickness, belly weight and dry curing yield (Table 1). Barrow pigs had greater firmness and dry curing yield $(P<0.05)$ compared to gilts, and barrow pigs also showed heavier boneless bellies compared to gilts and immunocastrated pigs. However, no significant difference was found due to immunological castration comparing to barrows and gilts on firmness and dry curing yield, even though, thickness was affected $(P>0.05)$.

Scramlin et al. (2008), in a study with 5 and $7.4 \mathrm{ppm}$ of ractopamine, observed a significant effect $(P<0.05)$ of gender (gilts and barrows) on belly characteristics. Similarly to the present study, barrow had greater firmness, making them more favorable for bacon slicing. The authors found no significant differences $(P>0.05)$ on thickness, length and process yield.

Cooking loss of bacon was not affected $(P>0.05)$ by gender; however, ractopamine influenced positively (Table 2 ) by decreasing cooking loss of bacon slices, which may suggest a better palatability, acceptation and less dry appearance. In contrast, Leick et al. (2010) observed no difference for cooking loss of bacon obtained from gilts and barrow pigs fed with different ractopamine levels in the diet ( 0 and $5 \mathrm{ppm})$. According to Stites et al. (1991) and Cantarelli et al. (2008), besides the process yield issue, other concern relates to the firmness, by which less firm bellies can be difficult for processing, especially in bacon slicing. Ractopamine and immunocastration did not affect the color of meat and fat of the bacon slices.

Immunocastrated pigs showed differences between genders due to lower fat content because these pigs remained longer period as entire males resulting in less fat and more lean tissue deposition, plus the action of ractopamine fed animals, resulting in less fat in carcass and muscle cuts (Boler et al., 2010). Brewer et al. (1995) observed an increase in cooking loss of sliced bacon due to an increase in belly thickness, corresponding to an increase in fat, which is the main component lost during cooking. Kemp et al. (1969), on the other hand, stated that the fat shrinks more than lean meat during cooking due to rendering of fat. The authors concluded that the quality of lean meat would have less effect on cooking loss than the amount of fat itself. Sillence (2004) reported an anabolic effect for this diet additive, ractopamine, which is more selective for muscle cells than to a possible catabolic action in adipose cells, since the tissue has small concentration of $\beta 3$-adrenergic receptors, specifically those related to lipid catabolism.

Rikard-Bell et al. (2009) also found no difference $(P>0.05)$ on belly weights from gilts and immunocastrated pigs fed with different ractopamine levels $(0 \mathrm{ppm}$ for one treatment and combination of 5 and $10 \mathrm{ppm}$ for the other two treatments). Similar results were reported by Uttaro et al. (1993), studying gender (barrows and gilts) with different dietary ractopamine levels $(0$ and $10 \mathrm{ppm})$ in pigs. The authors also observed increased belly weight and thickness of barrows compared to gilts, regardless of ractopamine level.

Although, differences in genetic and in the condition of animal production and slaughter were seen as confounding factors and expected to have some effects, they may have influenced the results, particularly for belly firmness and dry curing yield. Apparently, higher quality bellies of Agroceres PIC animals may have occurred since these animals have high immunological 
resistance while the genetic Topigs turns out to produce animals with high meat quality, according to Fuller et al. (1995).

Table 3 presents the results for bacon quality parameters, determined using digitally imaged data. There was a significant effect $(P<0.05)$ due to gender on total area. No interaction was found between gender and ractopamine $(P<0.05)$. Immunocastrated and gilts were not statically different and had the lowest total average area of slice compared to barrows, which also had heavier bellies (Table 4). Scramlin et al. (2008), found different results, on which an increase in meat area and secondary lean meat area of bacon slice were observed from gilts, even though genetic were not the same. In the same research, using digital imaging to determine secondary lean meat area, their results showed significant difference $(P<0.05)$ for pigs fed with ractopamine $(7.4 \mathrm{ppm})$ compared to the control.

Along the years, genetic improvements of pigs have greatly changed meat quality, towards consumer preference to bacon with higher lean meat content (Jabaay et al., 1976), which has led the pork slaughterhouses and the pork processing industries to emphasize on this demand (Barbut et al., 2008). According to Fuller et al. (1995), the Pietrain breed animals have higher belly weights and lower fat percent, which explains part of the results obtained in the present study, the highest lean meat percent (47.31\%) and the lowest fat percent $(52.69 \%)$ on bacon slices from Agroceres PIC, which was the result of crossing Pietrain, Landrace and Duroc.

The interaction between gender and ractopamine showed no significant difference $(P>0.05)$ on bacon quality parameters. The same results were obtained for Scramlin et al. (2008), for which there were no interactions for the same bacon characteristics due to gender and ractopamine at slightly different levels $(0,5$ and $7.4 \mathrm{ppm})$ from the present study.

Bacon from immunocastrated pigs, with thinner bellies $(3.4 \mathrm{~cm})$ had reduced percentage of fat area $(53.04 \%)$ compared to castrated $(55.69 \%)$, which also had thicker bellies $(3.7 \mathrm{~cm})$. In another study (Silva et al., 2016) with the same treatments, bellies from barrows had higher fat content (33.4\%) than bellies from immunocastrated males (26.6\%). However, Person et al. (2005) evaluated the appearance of bacon by consumers as affected by belly thickness. The authors observed that thicker bellies $(3.0 \mathrm{~cm})$ produced less attractive bacon than thinner bellies $(2.5 \mathrm{~cm})$, which also lead to leaner bacon.

The results of sensory quality are shown on Table 4 . The statistical results showed significant differences $(P<0.05)$ on appearance and odor due to gender. Consumer test results revealed preference for bacon from gilts and barrows for both attributes odor and appearance $(P<0.05)$; however, acceptability

Table 3. Results of bacon quality parameters as a function of gender and ractopamine level.

\begin{tabular}{|c|c|c|c|c|c|c|}
\hline & & $\begin{array}{c}\text { Primary } \\
\text { lean meat area } \\
\left(\mathrm{cm}^{2}\right)\end{array}$ & $\begin{array}{c}\text { Secondary lean } \\
\text { meat area } \\
\left(\mathrm{cm}^{2}\right)\end{array}$ & $\begin{array}{l}\text { Total area of slice } \\
\qquad\left(\mathrm{cm}^{2}\right)\end{array}$ & $\begin{array}{c}\text { Meat area } \\
(\%)\end{array}$ & $\begin{array}{c}\text { Fat area } \\
(\%)\end{array}$ \\
\hline \multirow{3}{*}{ Gender } & Gilt & 28.56 & 13.04 & $89.34^{\mathrm{b}}$ & 46.62 & 53.37 \\
\hline & Immunocastrated & 28.07 & 13.66 & $89.03^{\mathrm{b}}$ & 46.96 & 53.04 \\
\hline & SEM & 0.929 & 0.641 & 2.163 & 0.851 & 0.851 \\
\hline \multirow{4}{*}{$\begin{array}{l}\text { Ractopamine } \\
\text { (ppm) }\end{array}$} & 7.5 & 29.40 & 13.66 & 94.18 & 45.95 & 54.06 \\
\hline & SEM & 0.760 & 0.521 & 1.867 & 0.713 & 0.753 \\
\hline & $P$-value & 0.349 & 0.632 & 0.219 & 0.922 & 0.922 \\
\hline & $\mathrm{CV}(\%)$ & 19.1 & 28.0 & 14.7 & 11.3 & 9.64 \\
\hline
\end{tabular}

${ }^{\text {ab }}$ Means within the same column with different superscripts differ significantly at 5\% level of significance for gender and ractopamine level. SEM: Standard error of the mean for all treatments; CV: Coefficient of variation.

Table 4. Results of treatments on sensory quality of bacon as a function of gender and ractopamine level.

\begin{tabular}{|c|c|c|c|c|}
\hline & & & Appearance & Odor \\
\hline \multirow{5}{*}{ Gender } & Gilt & & $6.618^{\mathrm{ab}}$ & $6.630^{\mathrm{a}}$ \\
\hline & Barrow & & $6.999^{\mathrm{a}}$ & $6.518^{\mathrm{a}}$ \\
\hline & Immunocastrated & & $6.399^{b}$ & $6.000^{\mathrm{b}}$ \\
\hline & & SEM & 0.123 & 0.149 \\
\hline & & $P$-value & 0.003 & 0.006 \\
\hline \multirow{5}{*}{$\begin{array}{c}\text { Ractopamine } \\
\text { (ppm) }\end{array}$} & 0.0 & & 6.630 & 6.409 \\
\hline & 7.5 & & 6.708 & 6.350 \\
\hline & & SEM & 0.102 & 0.123 \\
\hline & & $P$-value & 0.547 & 0.723 \\
\hline & & CV (\%) & 24.0 & 30.2 \\
\hline
\end{tabular}

\footnotetext{
${ }^{\text {ab }}$ Means within the same column with different superscripts differ significantly at $5 \%$ level of significance for gender and ractopamine level. SEM: Standard error of the mean for all
} treatments; CV: Coefficient of variation. 
was above 6 ("liked moderately") for all treatments. Bacon from immunocastrated pigs had significantly lower score for odor than bacon from gilts and barrows ( $5=$ liked slightly; $6=$ liked moderately), although odor perception of bacon is a difficult task considering being cured, cooked and smoked. Font i Furnols et al. (2008) using trained panelists sensitive to androstenone and skatole (both responsible for boar taint), found no significant differences in acceptability among meat from gilts, barrows and immunocastrated pigs.

The average purchase intention of $57 \%$ consumers indicated that all bacon analyzed could be classified as definitely or probably would buy; however in another study, consumers showed a higher preference and intention to purchase for meat obtained from immunocastrated pigs compared to meat obtained from barrows (Font i Furnols et al., 2009).

\section{Conclusion}

The results obtained from this study showed that ractopamine may improve belly physical characteristics and cooking loss of bacon, suggesting that bacon slices would have higher palatability and acceptation by presenting less dry appearance. Also, ractopamine increased both dry curing and process yields.

The combined effects of ractopamine and immunocastration had low or no influence on $\mathrm{pH}$ and on meat and fat color of bacon. No interaction was found between ractopamine and immunocastration on belly physical characteristics and on bacon quality. In practical terms, despite what the statistical analysis showed for the sensory results, when consumers were offered bacon from immunocastrates and/or from ractopamine fed pigs, they did not find it strongly different from control bacon (gilts, castrated or not ractopamine fed pigs). Moreover, the results for immunocastrated pigs indicate that it could be an alternative for physical castration, which contributes to a high level of stress to the animal and to reduce the occurrence of boar taint. All these results indicate that the technologies of immnucastration and ractopamine can be combined with no further consequences for belly processing and to bacon quality, and with some advantages.

\section{References}

Agência Nacional de Vigilância Sanitária. (2001, January 2). Resolução RDC 12/2001: regulamento técnico sobre os padrões microbiológicos para alimentos. Diário Oficial [da] República Federativa do Brasil. Retrieved from http:// portal.anvisa.gov.br/documents/33880/2568070/ RDC_12_2001.pdf/15ffddf6-3767-4527-bfac-740a0400829b.

Apple, J. K., Kutz, B. R., Maxwell, C. V., Davis, M. E., Rakes, L. K., Johnson, Z. B., \& Armstrong, T. A. (2004). Effects of ractopamine and dietary fat source on quality characteristics of growing and finishing swine. Journal of Animal Science, 82(suppl. 1), 135.

Barbut, S., Sosnicki, A. A., Lonergan, S. M., Knapp, T., Ciobanu, D. C., Gatcliffe, L. J., Huff-Lonergan, E., \& Wilson, E. W. (2008). Progress in reducing the pale, soft and exudative (PSE) problem in pork and poultry meat. Meat Science, 79(1), 46-63. PMid:22062597. http:// dx.doi.org/10.1016/j.meatsci.2007.07.031.

Boler, D. D., Holmer, S. F., Duncan, D. A., Carr, S. N., Ritter, M. J., Stites, C. R., Petry, D. B., Hinson, R. B., Allee, G. L., McKeith, F. K., \& Killefer, J. (2010). Fresh meat and further processing characteristics of ham muscles from finishing pigs fed ractopamine hydrochloride. Journal of Animal Science, 89(1), 210-220. PMid:20817858. http:// dx.doi.org/10.2527/jas.2010-3041.

Brasil. Ministério da Agricultura, Pecuária e Abastecimento. (1997). Regulamento da inspeção industrial e sanitária de produtos de origem animal. Diário Oficial [da] República Federativa do Brasil, p. 241.

Brasil. Ministério da Agricultura, Pecuária e Abastecimento. (2000, January 17). Regulamento técnico de métodos de insensibilização para o abate humanitário de animais de açougue. Instrução normativa ${ }^{\circ}$ 3 de 17 de janeiro de 2000. Diário Oficial [da] República Federativa do Brasil.

Brewer, M. S., Stites, C. R., McKeith, F. K., Bechtel, P. J., Novakofski, J. E., \& Bruggen, K. A. (1995). Belly thickness effects on the proximate composition, processing, and sensory characteristics of bacon. Journal of Muscle Foods, 6(3), 283-296. http://dx.doi. org/10.1111/j.1745-4573.1995.tb00573.x.

Brumatti, R. C., \& Kiefer, C. (2010). Simulação técnico-econômica da inclusão de ractopamina em dietas de suínos em terminação. Arquivo Brasileiro de Medicina Veterinária e Zootecnia, 62(1), 163-171. http:// dx.doi.org/10.1590/S0102-09352010000100022.

Cantarelli, V. S., Zangeronimo, M. G., Almeida, E. C., Wolp, R. C., Pereira, L. M., \& Fialho, E. T. (2008). Qualidade de cortes de suínos recebendo ractopamina na ração em diferentes programas alimentares. Acta Scientiarum Animal Science, 2, 165-171.

Crome, P. K., McKeith, F. K., Carr, T. R., Jones, D. J., Mowrey, D. H., \& Cannon, J. E. (1996). Effect of ractopamine on growth performance, carcass composition, and cutting yields of pigs slaughtered at 107 and 125 kilograms. Journal of Animal Science, 74(4), 709-716. PMid:8727989. http://dx.doi.org/10.2527/1996.744709x.

Dunshea, F. R., Colantoni, C., Howard, K., McCauley, I., Jackson, P., Long, K. A., Lopaticki, S., Nugent, E. A., Simons, J. A., Walker, J., \& Hennessy, D. P. (2001). Vaccination of boars with a GnRH vaccine (Improvac) eliminates boar taint and increases growth performance. Journal of Animal Science, 79(10), 2524-2535. PMid:11721830. http:// dx.doi.org/10.2527/2001.79102524x.

Fayrer-Hosken, R. (2008). Controlling animal populations using anti-fertility vaccines. Reproduction in Domestic Animals, 43(Suppl 2), 179-185. PMid:18638121. http://dx.doi.org/10.1111/j.14390531.2008.01159.x.

Font i Furnols, M., Gispert, M., Guerrero, L., Velarde, A., Tibau, J., Soler, J., Hortos, M., Garcia-Regueiro, J. A., Pérez, J., Suarez, P., \& Oliver, M. A. (2008). Consumers' sensory acceptability of pork from immunocastrated male pigs. Meat Science, 80(4), 1013-1018. PMid:22063830. http://dx.doi.org/10.1016/j.meatsci.2008.04.018.

Font i Furnols, M., González, J., Gispert, M., Oliver, M. A., Hortós, M., Pérez, J., Suarez, P., \& Guerrero, L. (2009). Sensory characterization of meat from pigs vaccinated against gonadotropin releasing factor compared to meat from surgically castrated, entire male and female pigs. Meat Science, 83(3), 438-442. PMid:20416689. http://dx.doi. org/10.1016/j.meatsci.2009.06.020.

Fuller, M. F., Franklin, M. F., McWilliam, R., \& Pennie, K. (1995). The responses of growing pigs, of different Sex and genotype, to dietary energy and protein. Animal Science, 60, 291-298.

Gonzalez, J. M., Johnson, S. E., Stelzleni, A. M., Thrift, T. A., Savell, J. D., Warnock, T. M., \& Johnson, D. D. (2010). Effect of ractopamine-HCl supplementation for 28 days on carcass characteristics, muscle fiber morphometrics, and whole muscle yields of sixdistinct muscles of the loin and round. Meat Science, 85(3), 379-384. PMid:20416798. http://dx.doi.org/10.1016/j.meatsci.2010.02.004.

Jabaay, R. W., Forrest, J. C., Aberle, E. D., Courtenay, H. V., \& Judge, M. D. (1976). Bacon quality criteria and associated carcass 
traits. Journal of Food Science, 41(2), 431-437. http://dx.doi. org/10.1111/j.1365-2621.1976.tb00635.x.

Kemp, J. D., Moody, W. O., \& Fox, J. D. (1969). Effect of fatness and fresh pork quality on yield and quality of bacon and yield of ham. Journal of Animal Science, 28(5), 612-619. http://dx.doi.org/10.2527/ jas1969.285612x.

Leick, C. M., Puls, C. L., Ellis, M., Killefer, J., Carr, T. R., Scramlin, S. M., England, M. B., Gaines, A. M., Wolter, B. F., Carr, S. N., \& McKeith, F. K. (2010). Effect of distillers dried grains with solubles and ractopamine (Paylean) on quality and shelf-life of fresh pork and bacon. Journal of Animal Science, 88(8), 2751-2766. PMid:20407070. http://dx.doi.org/10.2527/jas.2009-2472.

Oliver, W. T., McCauley, I., Harrell, R. J., Suster, D., Kerton, D. J., \& Dunshea, F. R. (2003). A gonadotropin-releasing factor vaccine (Improvac) and porcine somatotropin have synergistic and additive effects on growth performance in group-housed boars and gilts. Journal of Animal Science, 81(8), 1959-1966. PMid:12926778. http:// dx.doi.org/10.2527/2003.8181959x.

Person, R. C., McKenna, D. R., Griffin, D. B., McKeith, F. K., Scanga, J. A., Belk, K. E., Smith, G. C., \& Savell, J. W. (2005). Benchmarking value in the pork supply chain: Processing characteristics and consumer evaluations of pork bellies of different thickness when manufactured into bacon. Meat Science, 70(1), 121-131. PMid:22063288. http:// dx.doi.org/10.1016/j.meatsci.2004.12.012.

Rentfrow, G., Sauberb, T. E., Alleea, G. L., \& Berg, E. P. (2003). The influence of diets containing either conventional corn, conventional corn with choice white grease, high oil corn, or high oil high oleic corn on belly/bacon quality. Meat Science, 64(4), 459-466. PMid:22063128. http://dx.doi.org/10.1016/S0309-1740(02)00215-2.

Rikard-Bell, C., Curtis, M. A., van Barneveld, R. J., Mullan, B. P., Edwards, A. C., Gannon, N. J., Henman, D. J., Hughes, P. E., \& Dunshea, F. R. (2009). Ractopamine hydrochloride improves growth performance and carcass composition in immunocastrated boars, entire boars, and gilts. Journal of Animal Science, 87(11), 3536-3543. PMid:19648492. http://dx.doi.org/10.2527/jas.2009-2002.
Scramlin, S. M., Carr, S. N., Parks, C. W., Fernandez-Dueñas, D. M., Leick, C. M., McKeith, F. K., \& Killefer, J. (2008). Effect of ractopamine level, gender, and duration of ractopamine on belly and bacon quality traits. Meat Science, 80(4), 1218-1221. PMid:22063860. http://dx.doi. org/10.1016/j.meatsci.2008.05.034.

Sillence, M. N. (2004). Technologies for the control of fat and lean deposition in livestock. Veterinary Journal (London, England), 167(3), 242-257. PMid:15080873. http://dx.doi.org/10.1016/j.tvjl.2003.10.020.

Silva, L. C. C., Darros-Barbosa, R., \& Silveira, E. T. F. (2016). Effects of ractopamine hydrochloride and immunological castration in pigs. Part 2. Belly quality characteristics and fatty acid composition. Food Science and Technology (Campinas.), (Submitted)

StatSoft. (2004). Statistica: data analysis software system: version 7. Retrieved from www.statsoft.com.

Stites, C. R., McKeith, F. K., Singh, S. D., Bechtel, P. J., Mowrey, D. H., \& Jones, D. J. (1991). The effect of ractopamine hydrochloride on the carcass cutting yields of finishing swine. Journal of Animal Science, 69(8), 3094-3101. PMid:1680116. http://dx.doi.org/10.2527/1991.6983094x.

Tavárez, M. A., Boler, D. D., Carr, S. N., Ritter, M. J., Petry, D. B., Souza, C. M., Killefer, J., McKeith, F. K., \& Dilger, A. C. (2012). Fresh meat quality and further processing characteristics of shoulders from finishing pigs fed ractopamine hydrochloride (Paylean). Journal of Animal Science, 90(13), 5122-5134. PMid:22952374. http://dx.doi. org/10.2527/jas.2012-5438.

Uttaro, B. E., Ball, R. O., Dick, P., Rae, W., Vessie, G., \& Jeremiah, L. E. (1993). Effect of ractopamine and sex on growth, carcass characteristics, processing yield, and meat quality characteristics of crossbred swine. Journal of Animal Science, 71(9), 2439-2449. PMid:8104922.

Vold, E. (1970). Fleischproduktionseigenschaften bei Ebern und Kastraten. IV. Organoleptische und gaschromatografische Untersuchungen wasserdampfflüchtiger Stoffe des Rückenspeckes von Ebern. Meldinger fra Norges Landbrukshøgskole, 49, 1-25. 